\title{
En1 and Wnt signaling in midbrain dopaminergic neuronal development
}

\author{
Maria TM Alves dos Santos and Marten P Smidt
}

\begin{abstract}
Dopaminergic neurons of the ventral mesodiencephalon are affected in significant health disorders such as Parkinson's disease, schizophrenia, and addiction. The ultimate goal of current research endeavors is to improve the clinical treatment of such disorders, such as providing a protocol for cell replacement therapy in Parkinson's disease that will successfully promote the specific differentiation of a stem cell into a dopaminergic neuronal phenotype. Decades of research on the developmental mechanisms of the mesodiencephalic dopaminergic (mdDA) system have led to the identification of many signaling pathways and transcription factors critical in its development. The unraveling of these pathways will help fill in the pieces of the puzzle that today dominates neurodevelopment research: how to make and maintain a mdDA neuron. In the present review, we provide an overview of the mdDA system, the processes and signaling molecules involved in its genesis, with a focus on the transcription factor En1 and the canonical Wnt pathway, highlighting recent findings on their relevance - and interplay - in the development and maintenance of the mdDA system.
\end{abstract}

\section{The mesodiencephalic dopaminergic system}

The mesodiencephalic dopaminergic (mdDA) system has been the focus of intense scientific research due to its involvement in numerous behavioral and neurological disorders and thus its clinical relevance. The neurotransmitter dopamine (DA) is present in different areas of the brain, such as the hypothalamus, the olfactory bulb and the mid-forebrain. In this last area, mdDA neurons are the main source of dopamine in the mammalian central nervous system (CNS), attributable to two ventral groups of neurons: the substantia nigra pars compacta (SNc) and the ventral tegmental area (VTA) [1-3]. The main innervation targets of mdDA neurons are the basal ganglia. The neurons of the SNc innervate the dorsolateral striatum and caudate putamen forming the nigrostriatal pathway. Neurons of the VTA project to the ventral striatum (nucleus accumbens, amygdala and olfactory tubercle) as part of the mesolimbic system and establish additional ascending connections to the prefrontal cortex forming the mesocortical system. These ventral midbrain nuclei modulate specific brain functions according to its distinct projection fields. The

\footnotetext{
* Correspondence: m.p.smidt-2@umcutrecht.nl
Rudolf Magnus Institute of Neuroscience, Department of Neurosciences and

* Correspondence: m.p.smidt-2@umcutrecht.nl
Rudolf Magnus Institute of Neuroscience, Department of Neurosciences and Pharmacology, University Medical Center Utrecht, Universiteitsweg 100, 3584 CG Utrecht, The Netherlands
}

(c) 2011 Alves dos Santos and Smidt; licensee BioMed Central Ltd. This is an Open Access article distributed under the terms of the Creative Commons Attribution License (http://creativecommons.org/licenses/by/2.0), which permits unrestricted use, distribution, and reproduction in any medium, provided the original work is properly cited.

SNc is involved in the control of voluntary movement and body posture, and its selective degeneration leads to Parkinson's disease (PD) $[4,5]$. The mesocortical and mesolimbic systems, on the other hand, are involved in the modulation and control of cognitive and emotional/ rewarding behaviors, and their dysfunction is involved in the pathogenesis of various affective disorders, such as addiction [6-8], depression [9] and schizophrenia $[10,11]$. Drug abuse, depression and PD constitute highly common health disorders, which explains the intense research in recent years on the mechanisms and factors involved in the generation and survival of mammalian mdDA neurons.

\section{mdDA neurogenesis and differentiation}

The development of an organ, such as the midbrain, implies the sequential occurrence of developmental cascades over time, while these might overlap in time and space [12-14]. During early neuronal induction and patterning, a precise molecular coding along the anteriorposterior and dorsal-ventral axis in the developing neural tube provides positional cues that are crucial in pattern formation [15-17]. Anterior-posterior patterning leads to the genesis of morphogenetic domains - forebrain, midbrain, isthmus and hindbrain - whereas dorsal-ventral patterning results in crosswise subdivisions in 
the brain throughout the neuroaxis - floor plate, basal plate, alar plate and roof plate [16,18,19] (Figure 1A).

The successful regionalization of the early CNS is necessary for the subsequent correct commitment and positioning of mdDA neurons later on in development [17]. The creation of the isthmus, a neuroepithelial signaling center localized at the midbrain-hindbrain boundary $(\mathrm{MHB})$, together with the ventral signaling center from the floor plate, are essential for pattern formation and the generation of mdDA neurons in the developing embryos $[13,15,17]$. The isthmus is characterized by the expression of the fibroblast growth factor 8 (Fgf8) and the floor plate by the expression of sonic hedgehog (Shh) [20,21]. The intersection of these secreted factors provides the positional information that determines where the mdDA progenitor domain will arise [15,20,22-24]. While Fgf8 acts as an anterior-posterior morphogen [25], the dorsoventral axis is determined by the ventralizing Shh in the floor plate and the dorsally secreted bone morphogenetic proteins by the roof plate [26-28]. The isthmus is established by the opposing expression domains of two transcriptional repressors: Gbx2 in the presumptive hindbrain and
Otx2 in the presumptive mid/forebrain [12,29]. Although Otx2 and Gbx2 are not necessary for the induction of MHB genes (such as Fgf8), they are essential for the correct positioning of their expression domains [30]. Other factors as well are involved in the induction and maintenance of mdDA progenitors in the ventral midbrain: the Wnt factors [31], Engrailed (En)1 and En2 [32], Pax2/5 [33,34], Lmx1a, Msx1 and Lmx1b $[35,36]$, and Foxa2 [37,38]. For comprehensive reviews see [39-41]. The interplay of all these factors in the ventral midbrain forms a grid of graded cues in which neural progenitors follow different cell fates depending on their position.

mdDA precursors will eventually become fully differentiated mdDA neurons when they start expressing an array of genes that are essential for DA signaling. These key factors comprise the enzymes tyrosine hydroxylase (Th) and the L-aromatic amino acid decarboxylase (Aadc), which catalyze the conversion of L-tyrosine to L-DOPA and L-DOPA to dopamine, respectively; the vesicular monoamine transporter (Vmat2), which is required for vesicular storage and release of dopamine; and the dopamine transporter (Dat), involved in the re-

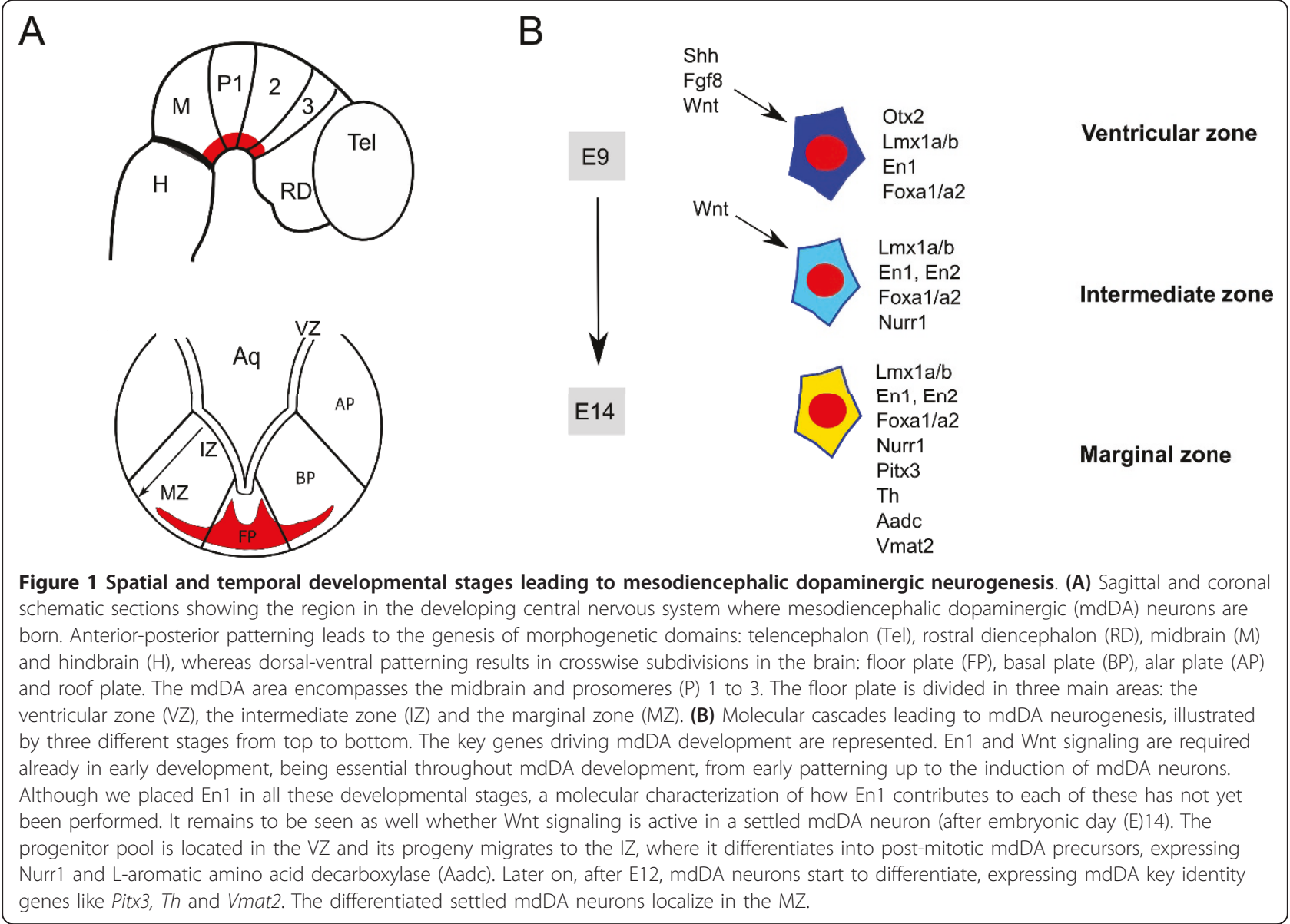


uptake of DA from the synaptic cleft. These proteins, among others, are essential in the make-up of dopaminergic neurons. Several transcription factors, such as Nurr1, Pitx3, Lmx1b, are critical for the specification of neuronal identity (that is, for the expression of the above mentioned mdDA-specific factors) and maturation and survival of postmitotic mdDA neurons $[35,42-44]$.

Around mouse embryonic day (E)10, proliferative mdDA progenitors present in the ventricular zone (VZ) begin migrating ventrally along radial glia towards the pial surface $[45,46]$ (Figure 1B). These migrating precursors, besides continuing to express a large set of genes from early mdDA progenitor specification, such as those encoding En1/2, Lmx1a/b and Foxa1/2, start expressing Aadc [14] and, at E10.5, the Nurr1 orphan nuclear receptor [42], after which they exit the cell cycle and become postmitotic [47] (Figure 1B). At this stage these cells should be considered postmitotic mdDA precursors since they are not yet fully differentiated mdDA neurons [48]. Th-positive cells were first reported to appear in the mouse ventral midbrain between E9.5 and E11.5 $[49,50]$. At this time-point the mdDA precursors become dopaminergic neurons as they also acquire the expression of the homeodomain transcription factor Pitx3 [35,45,51]. mdDA neurogenesis peaks around day E12.5 and declines thereafter [50,52]. Once the ventricular-to-pial migration is accomplished by E13, the mdDA neurons take up their position corresponding to the future SNc and VTA [45]. Hereafter, until the first postnatal weeks, the mdDA neurons start extending axonal outgrowths towards their target projection areas within the striatum and cortex $[45,53]$.

To assume that not every cell in the mdDA system is the same, following exactly equal transcriptional programs, is plausible if we consider the existence of a positional grid of signals during neuronal development, each coordinate specifying a different (if modest at times) cell program. This existence of neuronal subsets within the ventral midbrain is now an accepted fact; for example, one difference between the SNc and the VTA is that they present a different temporal order of Th and Pitx3 gene expression [54]. This difference, together with other differential aspects, might explain why the SNc is more vulnerable than the VTA to neuronal degeneration $[4,5,55]$. For detailed reviews on mdDA neurogenesis, see [56-58].

\section{Engrailed}

Engrailed proteins are bifunctional homeodomain transcription factors [59], highly conserved throughout the animal kingdom $[60,61]$. In the murine genome there are two engrailed paralogs, En1 and En2, both essential in embryonic development. En1 is already expressed at the one-somite stage (E8) while En2 expression appears half a day later [62]. The expression domain of engrailed (En1/2) comprises the neuroepithelium of the posterior midbrain and anterior hindbrain, which will later give rise to the cerebellum, the colliculi and the ventral midbrain nuclei [63]. En1 is expressed highly by all mdDA neurons from the moment they start to differentiate (around E11) and continuously into adulthood, whereas En2 is strongly expressed in only a subset of them $[32,64]$. Outside the CNS, En1 is expressed in the cranial mesenchyme, the mandibular arches, the vagus nerve, the dorsal root ganglia, the sympathetic ganglia, the somites, the heart, the cloaca, and the tail and limb buds [64-67]. In the adult brain, both are expressed in the pons and the substantia nigra and En2 alone is found in cerebellar cells [62,67-69].

Today, after two decades of research, a multitude of evidence has been produced establishing engrailed proteins as key players in the embryonic development of the CNS (Figure 2A). Up until now, it has been shown that they are involved in multiple developmental processes: the regionalization in early embryogenesis, including isthmic organization [13,67,70-72]; neuronal identity, such as the control of glial-neuronal fate in the grasshopper [73] and serotonergic midline neurons in Drosophila [74]; axonal outgrowth and pathfinding in insects, birds and mammals [75-80]; and the identity specification of subsets of vertebrate interneurons in the spinal cord $[68,81]$. Engrailed proteins, besides functioning as transcription factors (localized in the nucleus), have also been characterized as secreting survival factors [80,82-84], where about $5 \%$ of the engrailed protein is found associated with membrane vesicles, becoming secreted and internalized by cells $[82,85,86]$. Furthermore, En1 secretion appears to be a regulated process [87]. These studies have shown that engrailed proteins can function as signaling molecules, acting in a paracrine manner in mdDA neurons. In a recent study, mdDA neuronal loss in $\mathrm{EnI}^{+/-}$adult mice was antagonized by En2 recombinant protein infusions in the midbrain [88], showing both the ability of engrailed to act as a signaling molecule and suggesting a biochemical equivalence between En1 and En2.

\section{Engrailed in the development of mdDA neurons}

The spatial and temporal expression of En 1 in the brain, as mentioned above, is mainly restricted to the midhindbrain junction and coincident with the development and maintenance of mdDA neurons. To elucidate a gene's role within a certain biological system, such as the dopaminergic system in the midbrain, the study of its natural mutant (when available) or its engineered knockout is essential. The brain phenotypes of $E n 1$ and En2 mutants are quite different despite their similar 


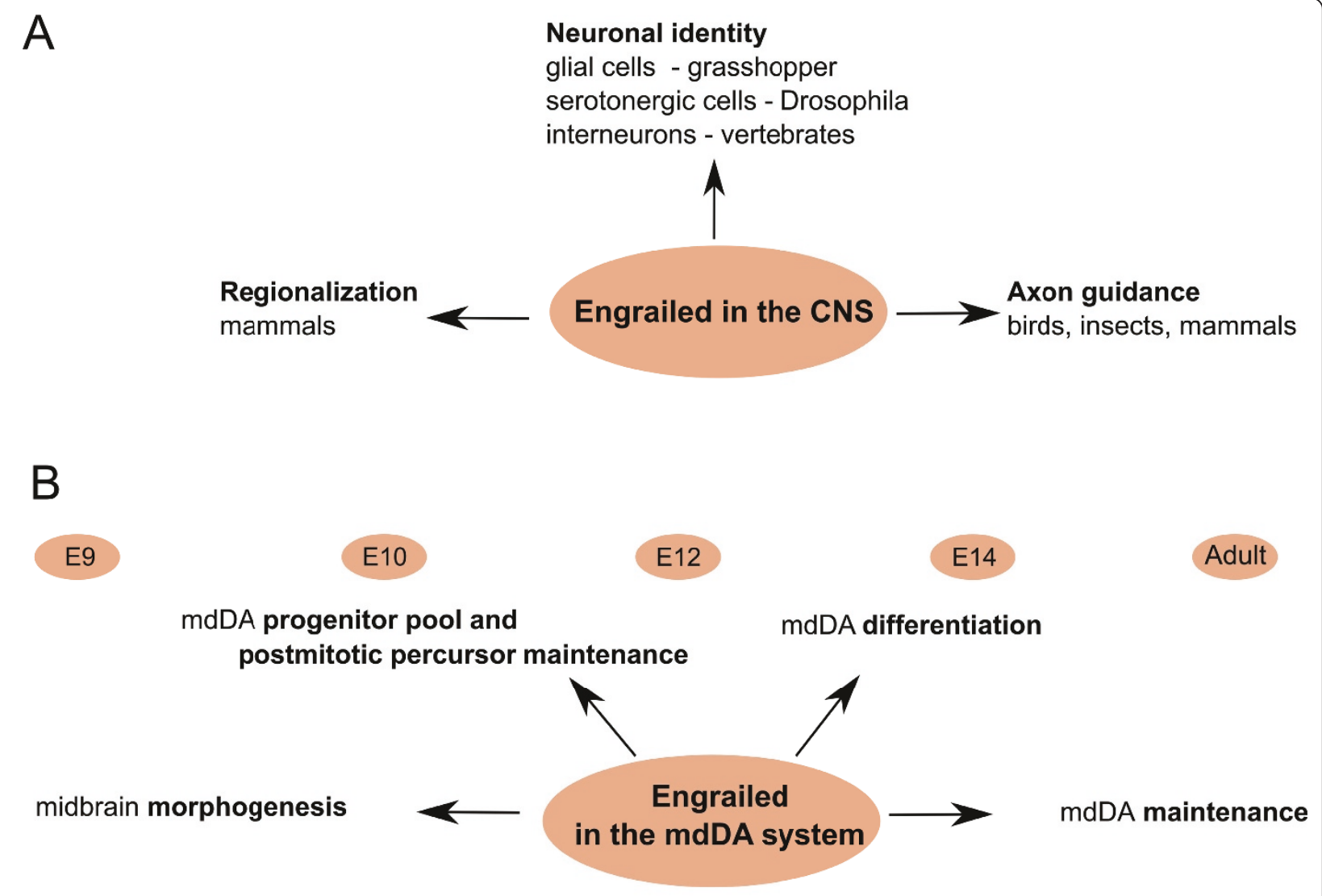

Figure 2 The impact of the engrailed genes in the development of the central nervous system and the mesodiencephalic dopaminergic system. (A) Engrailed proteins are key players in diverse processes during embryonic development of the central nervous system (CNS), including patterning, axonal guidance and neuron specification. (B) Engrailed proteins are essential in mesodiencephalic dopaminergic (mdDA) neuron development from an early stage, where they are involved in morphogenesis and mdDA neurogenesis, and in the adult, where they play a role in mdDA neuron maintenance $\mathrm{E}$, embryonic day.

expression patterns and structurally related protein products [67]. The En 2 single mutant is viable and fertile and exhibits a mild cerebellar phenotype involving a reduction in the size of the cerebellum and colliculi with an alteration in its folding pattern, while the mdDA population remains normal $[69,89,90]$. Generated En1 null mutant mice die at birth and have multiple defects, such as abnormal forelimbs and sternum and a deletion of hindbrain tissue resulting in loss of most of the cerebellum and colliculi [67].

The mid-hindbrain phenotype in En1 mutant mice, together with corroborative data from other mutants in which En1 expression is absent, such as the Wnt1 mutant [91], clearly pinpoint En1 as a critical protein for normal development of mid-hindbrain structures, already starting from its earliest expression period in the neural tube. However, detailed molecular characterization of the mdDA system in the En1 single-null mutant is lacking in the literature, the focus having been thus far on the En1/En2 double knockout.
A few studies have shown the biochemical equivalence between En1 and En2. En2 can functionally replace En1 when knocked-in to the En1 locus, allowing for normal midbrain development and survival of the murine $E n 1$ null mutant [92]. This suggests that the two paralogs are maybe redundant and functionally equivalent [60]. Functional equivalence across phyla has also been confirmed by using Drosophila engrailed (en) to replace murine En1 [93]. However, neither en nor En2 could rescue the limb defects caused by loss of En1 function [93]. It is generally accepted that the main functional differences between the engrailed null mutants are due to their different temporal and spatial expression and not to different molecular properties [51]. However, En1 and En2 differ substantially in their compensatory abilities to maintain ventral midbrain dopaminergic neurons. The complete loss of mdDA neurons only occurs when all four alleles are deleted $\left(E n 1^{-1-} ; E n 2^{-/}\right)$[32]. This study by Simon et al. study describes that mdDA neurons are induced, become postmitotic and express 
Th, but this entire mdDA population is lost by E14 due to cell loss [32]. They compare all intermediate genotypes of En1/En2 and show that engrailed is required in mice for the survival of dopaminergic neurons of the SNc and VT in a gene dose-dependent manner, with one En1 allele sufficient to produce a wild-type phenotype, while one En2 allele cannot [32]. However, in the $E n 1^{-1-}$ mutant there seems to be no significant alterations in the organization of the mdDA system at birth, with the number of midbrain dopaminergic neurons remaining unaffected $[32,67]$. Furthermore, the engrailed requirement for the survival of mdDA neurons is cellautonomous and not caused by the large deficiency of the surrounding midbrain tissue [51].

In more recent studies focusing on the $\mathrm{En1}^{+/-}$genotypes, the $E n 1^{+/}$; $E n 2^{-/}$mutant showed no apparent embryonic phenotype, while the adult had a phenotype resembling key pathological features of PD [94]. The postnatal mutant mice showed a specific and progressive degeneration of dopaminergic neurons in the substantia nigra during the first 3 months (other DA groups in the mesodiencephalon were not affected), resulting in diminished storage and release of dopamine in the caudate putamen accompanied by motor deficits (akin to akinesia and bradykinesia), and a lower body weight [94]. Interestingly, another study shows that in $E n 1^{+/-}$ animals, in an En2 wild-type background, the number of dopaminergic neurons in the SNc and VTA slowly decrease between 2 and 6 months after birth [88]. This reduction in dopaminergic neurons is stronger in the SNc. The dopaminergic neuronal cell death was paralleled by a substantial decrease in striatal DA, impaired motor skills, and listless behavior. Together, these studies demonstrate that engrailed genes have both important embryonic and adult physiological functions (Figure $2 \mathrm{~B}$ ), and that their deregulation leads to progressive dopaminergic cell death in the adult [88], a characteristic of PD pathology.

\section{En1 and Parkinson's disease}

The pathological hallmark of PD is the selective and progressive degeneration of dopaminergic neurons in the SNc [5]. En1 does affect the survival of this population during embryonic development $[88,94]$. Furthermore, the deletion of one $E n 1$ allele leads to massive cell death in the mdDA system of young adult mice [88,94], making $E_{n} 1$ a potential gene in the molecular cascade leading to progressive cell death in the neuropathology of PD. Recently, Sgado et al. [95] observed that En1 heterozygous adult mice present a significant reduction in striatal DA levels accompanied by a reduction in the number of nigral dopaminergic neurons, corroborating Sonnier's work [88]. Furthermore, the $\mathrm{En} 1^{+-}$ mice show motor deficits together with anhedonia, decreased social interactions and depression-like behaviors, which are reminiscent of symptoms observed in PD [96]. In PD, apoptosis is viewed as the mechanism leading to nigral DA cell death [97-99]. Interestingly, in the absence of both Engrailed genes, mdDA neurons undergo caspase-3-mediated apoptosis [51]. Noteworthy, $\alpha$-synuclein, a protein implicated in PD [100], seems to be regulated by engrailed $[51,101]$. In a recent study, genetic variants in the $E n 1$ gene showed a significant association with $\mathrm{PD}$, indicating that these polymorphisms are potential genetic risk factors for sporadic PD [102]. All the evidence so far points to the core importance of $\mathrm{En} 1$ in the maintenance of mdDA neurons, making the En1 mutant a plausible model for PD research.

\section{Wnt signaling}

A small number of signaling pathways are vital and used repeatedly in the developmental processes of all metazoa. One such core pathway is the Wnt signaling pathway. Wnt signaling was initially characterized in the late 1980s during embryonic development studies of Drosophila melanogaster, when it became clear that it was a key event for segmental and spatial organization of the body plan (reviewed in [103]). The term 'Wnt' is derived from a combination of the Drosophila wingless (wg) and the mouse homolog Int1 (subsequently Wnt1) proteins $[104,105]$. Wnts refer to the extracellular ligands of the pathway, which comprise a family of secreted glycolipoproteins able to interact with cell surface receptors eliciting a variety of intracellular responses. Being lipid modified, Wnts are hydrophobic in nature and localize preferentially in the extracellular matrix and cell membranes $[106,107]$.

To date, 19 distinct Wnts have been identified in mammals [108]. Wnt gene diversity is also observed in other animals like Drosophila, Caenorhabditis elegans and Xenopus, as well as in the ancient metazoan phylum Cnidarians [109], showing not only that Wnts are evolutionarily conserved but that Wnt gene diversity arose early in evolution and is in itself required for successful animal development. Indeed, Wnt signaling is crucial in embryonic development, from gastrulation and early pattern formation to organogenesis [110], and in adult organisms, where it plays a central role in the maintenance of tissue homeostasis and stem cell regulation [111]. Namely, Wnt signaling controls diverse processes, such as cell proliferation, self-renewal, cell polarity, cell death and cell fate specification [112-115]. Wnts can also function as morphogens, acting in both short- and long-range signaling, modulating target cells in a doseand distance-dependent manner [116-119]. This pivotal and complex role of Wnt signaling in such a myriad of biological processes implies that its deregulation leads to 
disease, such as cancer, congenital disorders and degenerative diseases [120-124].

The complexity of Wnt signaling is due, in the first place, to the large variety of ligands and receptors involved in Wnt signal transduction, allowing for an impressive number of possible ligand-receptor interactions [125]. For example, there are the frizzled receptors (ten Frizzled (Fz) receptor homologs in mammals) and the recently described non-Fz receptors, the RYK and Ror/Tyr kinases (reviewed in [126,127]). Secondly, Wntreceptor interactions can produce a variety of intracellular responses, since Wnt target genes are diverse and context-dependent $[115,128]$. The Wnt signaling pathways have been characterized as either canonical or non-canonical. For extensive and up-to-date reviews on the Wnt receptors and pathways, see $[126,129,130]$. In this review the focus will be primarily on the canonical pathway.

\section{Canonical Wnt signaling}

The best understood and most extensively studied of the Wnt pathways is the $\beta$-catenin-dependent Wnt signal transduction pathway (Wnt/ $\beta$-catenin), otherwise known as the canonical pathway. This pathway relays its signals by stabilizing $\beta$-catenin protein in the nucleus where it will be part of transcriptional complexes mediating key developmental gene expression programs [115]. Besides being the key factor in Wnt canonical signaling, $\beta$-catenin functions as a structural adapter protein linking cadherins to the actin cytoskeleton, in particular interacting with both E-cadherin and $\alpha$-catenin to mediate cell adhesion [131]. The focus of past and recent research on canonical Wnt signaling is explained by the imperative role it has in development and disease, and in stem cell specification and maintenance in various tissues and organs, including the brain (reviewed in [112,132-134]). Wnt- $\beta$-catenin signaling inactivation in vertebrates has also been implicated in other diseases, such as heart disease [135] and Alzheimer's [136-139]. The range of action of Wnt $/ \beta$-catenin signaling spans a few hours, and that is why its activity is observed mainly in contexts of cell-fate determination and tissue homeostasis [140].

\section{Canonical signaling mechanism}

In the absence of Wnt stimulation, $\beta$-catenin is tagged for degradation by a cytoplasmic ' $\beta$-catenin destruction complex'. This complex is assembled by the scaffolding protein Axin and comprises glycogen synthase kinase (GSK) $3 \beta$, casein kinase 1 and the adenomatous polyposis coli (APC) protein and others, which function by capturing 'surplus' $\beta$-catenin that is not involved in cell adhesion $[122,132]$. Once $\beta$-catenin is bound by Axin and APC, which act by efficiently positioning $\beta$-catenin and the kinases together, phosphorylation of $\beta$-catenin occurs by a dual kinase mechanism, whereby phosphorylation by casein kinase I triggers further phosphorylation by GSK3 $\beta$ [141]. This tagging results in $\beta$-catenin being recognized by $\beta$-Trcp, a ubiquitin ligase, causing $\beta$-catenin ubiquitination and subsequent proteasomal degradation [142]. In this manner, despite being continuously synthesized in the cell, the levels of cytosolic $\beta$-catenin are kept low, thus preventing it from accumulating in the nucleus. When Wnts bind to Fz transmembrane receptors and low-density lipoprotein receptor-related protein co-receptors (Lrp5 or Lrp6; Figure 3(1)), the scaffolding protein dishevelled (Dvl) joins this receptor complex, causing sequestration of Axin and, thereby, the dissolution of the $\beta$-catenin destruction complex [143-147] (Figure 3(2)). Consequently, $\beta$-catenin is not marked for degradation and is stabilized as a hypophosphorylated form, accumulating in the cytoplasm (Figure 3(3)), with preferential nuclear localization (Figure $3(4)$ ). Once in the nucleus, $\beta$-catenin binds to the $\mathrm{T}$ cell factor/lymphoid enhancer factor (TCF/LEF) family of DNA-binding factors, which bind to target promoter sequences via a specific DNA-binding domain in TCFs to form a

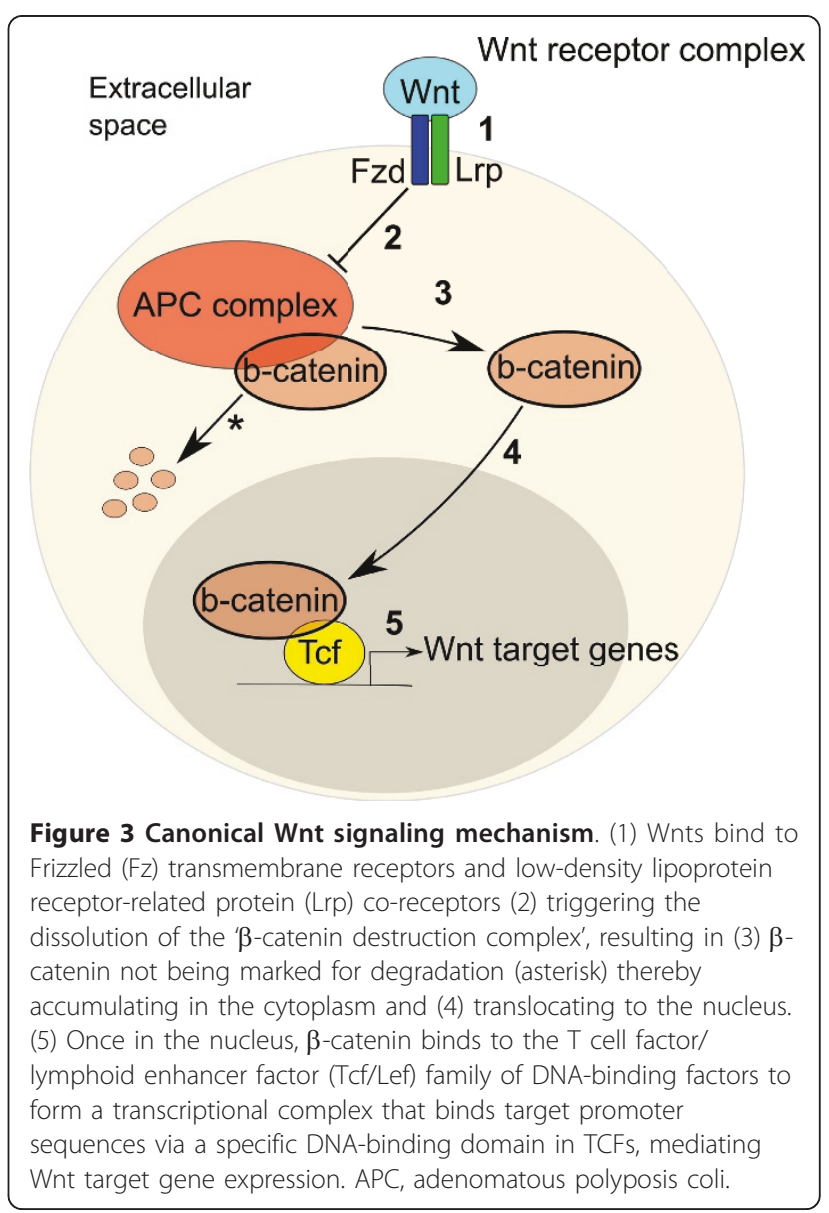


transcriptional complex that mediates Wnt target gene expression [122,123] (Figure 3(5)). Furthermore, $\beta$-catenin is essential as a docking platform for various transcriptional co-activators and chromatin remodeling complexes to stimulate transcription $[107,148]$.

\section{Wnt signaling crosstalk with key signaling pathways}

$\beta$-catenin/TCF transcriptional activity can be turned on by signaling molecules other than Wnt proteins (reviewed in [149]). For example, insulin and insulin-like growth factor- 1 promote $\beta$-catenin nuclear translocation and its binding to TCF on Wnt target gene promoters [150]. $\beta$-catenin also interacts with forkhead box $\mathrm{O}$ (FOXO) transcription factors to mediate protection against oxidative stress. In this case, FOXO proteins (which are active in stress signaling) will compete with TCF factors (which are active in development and proliferation) for the limited pool of free $\beta$-catenin [151-153]. Noteworthy, insulin and growth factors will have a role in this Foxo/TCF competition by antagonizing the function of FOXOs via a phosphorylationmediated nuclear exclusion process [154]. Finally, crossregulation of canonical Wnt signaling with that of nuclear receptors) has been observed, including a mutual regulation between Nurr1 and canonical Wnt signaling (for a review, see $[155,156])$.

\section{Wnt signaling in CNS development}

Recent studies have provided us with a more complete picture of the dynamic expression patterns of Wnts, their receptors and co-factors during development and adulthood (for a review, see $[157,158])$. The expression of Wnt signaling components during development of the CNS has also been described. To begin with, many Fz receptors are expressed in the mouse brain $[139,159]$, including Ryk, the lipoprotein receptor-related protein co-receptor [160] and the receptor tyrosine kinase-like orphan receptor (Ror) family [161]. Secondly, various Wnts are expressed in the developing CNS and peripheral nervous system, in overlapping and complementary patterns [162]. More and more evidence has surfaced corroborating the key role of Wnt signaling in the developing neural tube and brain [117]. Indeed, Wnt signaling seems to take part in most of the processes needed to generate a fully functional neuron (Figure 4A) from a neuronal stem cell, participating in early events, such as neuronal induction [163], anteriorposterior patterning and morphogenesis [164-167] and neuronal precursor proliferation [168-174], as well as in later processes, such as neuronal differentiation in the spinal cord [175], neuronal stem cells [176,177] and cortical neuronal precursors [178], neuronal cortical migration in mice [179], axon guidance in Drosophila [180] and in mice [181-183], synaptogenesis [184-186], synaptic differentiation $[187,188]$, dendritogenesis $[189,190]$ and neurogenesis in the telecephalon and hindbrain of adult mice [191-193].

\section{Wnt signaling in mdDA neurons}

Wnt signaling has a known and pivotal impact on mdDA neuron development (Figure 4B). To begin with, midbrain morphogenesis is regulated by Wnt signaling. Wnt1 mutant mice present an abnormal posterior midbrain, isthmus and rostral hindbrain, unveiling the essential role of Wnt signaling in MHB formation $[194,195]$. Other studies support the central role of the canonical pathway in the patterning of the MHB region, where the direct inactivation of $\beta$-catenin in a specific manner in the MHB mimics the Wnt1 mutant phenotype $[170,196]$. Furthermore, mutant mice for the Wnt receptor Lrp6 also phenocopy some of the Wnt1 mutant defects [160,197] and Fzd3 and Fzd6 double mutants show a severe impairment of midbrain morphogenesis [198]. In addition, Wnt1 directly regulates the expression of Otx2, a factor involved in midbrain morphogenesis, in a Wnt1-Lmx1a autoregulatory loop during embryonic development [199].

The proliferation and differentiation of midbrain dopaminergic neurons during ventral midbrain neurogenesis depend on Wnt signaling (reviewed in [31,200]). Already during early midbrain development, several members of the Wnt family are expressed and seem to be tightly regulated in a spatiotemporal way $[158,159,162,201,202]$. In particular, $\beta$-catenin transcriptional activity has been observed to take place in the developing mouse midbrain before the birth of Th-positive neurons (at E10.5), with stronger intensity in the Nurr1 expression domain [201]. It seems that activation of the Wnt $/ \beta$-catenin pathway contributes to increased DA neurogenesis during development: $\beta$-catenin promotes midbrain dopaminergic neurogenesis in vivo [203] and the stabilization of $\beta$-catenin in ventral mesencephalic precursors, by GSK3 $\beta$ inhibition, leads to an increase in DA differentiation [204,205]. In these two recent studies, a targeted deletion of $\beta$-catenin in ThIRES-Cre; $\beta-\mathrm{Ctn}^{\mathrm{fl} / \mathrm{fl}}$ mutants resulted in reduced mdDA neurogenesis [205]. More recently, the same group reported that the constitutive activation of $\mathrm{Wnt} / \beta$-catenin signaling in the ventral midbrain of the Th-IRES$\mathrm{Cre} ; \beta-\mathrm{Ctn}^{\mathrm{Ex} 3 /+}$ mutants revealed a significant increase in the number of dopaminergic neurons as well as an increase in the number of committed progenitors, in line with their previous work [206]. On the other hand, activation of $\beta$-catenin in Shh-Cre; $\beta$-Ctn ${ }^{\mathrm{Ex} 3 /+}$ mutants led to the expansion of dopaminergic progenitors by reducing their exit from the cell cycle, with a concomitant reduction in the number of dopaminergic neurons more intensely in the SNc [206]. This suggests an opposing role for $\mathrm{Wnt} / \beta$-catenin signaling in early and 
A

\section{General developmental processes}

cell proliferation, cell death

cell polarity, cell fate specification act as morphogens

CNS early development gastrulation pattern formation morphogenesis neuronal percursor proliferation

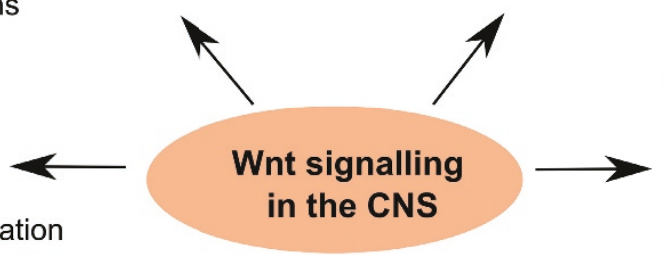

Adulthood

tissue homeostasis

stem cell regulation

B

E9

mdDA progenitor pool and postmitotic percursor maintenance

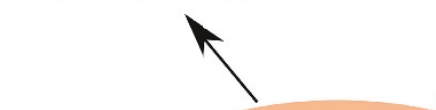

midbrain morphogenesis

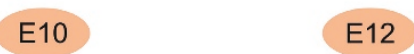

E12
CNS late development neuronal migration neuronal differentiation axon guidance synaptogenesis and dendritogenesis

Figure 4 Wnt signaling during the central nervous system and mesodiencephalic dopaminergic neuron development. (A) Wnt signaling is critical in embryonic development, controlling diverse processes, such as cell proliferation and cell polarity. It is involved during early central nervous system (CNS) development in gastrulation, early pattern formation, morphogenesis and precursor proliferation, in late CNS development in processes such as neuronal differentiation and migration, and in adult organisms, where it plays a central role in the maintenance of tissue homeostasis and stem cell regulation. Wnt signaling controls diverse processes, such as cell proliferation, cell polarity, cell death and cell fate specification Wnts can also function as morphogens in both short- and long-range signaling, modulating target cells in a dose- and distancedependent manner. (B) Wnt signaling is involved in mesodiencephalic dopaminergic (mdDA) neuron development from early on, where it is involved in morphogenesis, and later on as well in mdDA differentiation.

late mdDA development. Another study showed that Wnt1 activation enhanced the differentiation of mouse embryonic stem cells to mdDA neurons [199]. Wnt1 was also found to be required for the terminal differentiation of midbrain dopaminergic neurons at later stages of embryogenesis [207]. In addition, Wnt2 was recently identified as a novel regulator of dopaminergic progenitors, necessary in their proliferation; Wnt2-null mice therefore have decreased numbers of dopaminergic neurons [208].

In the next two sections we focus on what is known about Wnt signaling in connection to two decisive transcription factors involved in the development of the mdDA neurons, Nurr1 and En1.

\section{Wnt signaling and Nurr1}

It has been shown so far that activation of the Wnt/ $\beta$ catenin pathway contributes to increased mdDA neurogenesis during development, that is, that it regulates the proliferation and differentiation of ventral mesodiencephalic Nurr1 precursors in vivo [203]. Taking into account the data as described, Kitagawa et al. [156] tested the possibility of Wnt signaling regulating Nurr1 activity, and found a convergence between Nurr1 transcriptional regulation and Wnt signaling in cell culture. In short, Wnt signaling via $\beta$-catenin enhanced the transcriptional activity of Nurr1 in cells, at Nurr1 responsive elements (NREs), leading to $T H$ promoter activation (Figure 5A). In the absence of $\beta$ catenin, Nurr1 is associated with Lef1 in co-repressor complexes on NREs. After activation of Wnt signaling, $\beta$-catenin interacts with Nurr1 on NREs, competing with Lef1 for Nurr1 binding, resulting in the disruption of co-repressors from the Nurr1 complex and the concomitant recruitment of coactivators, such as CBP (Creb binding protein) [156] (Figure 5A). $\beta$-catenin functions, so it seems, as a transcriptional cofactor for Nurr1. Small interfering RNAs targeting Nurr1 abolished CBP and $\beta$-catenin association with the NRE in the $T H$ promoter [156]. On the other hand, Nurr1 was 


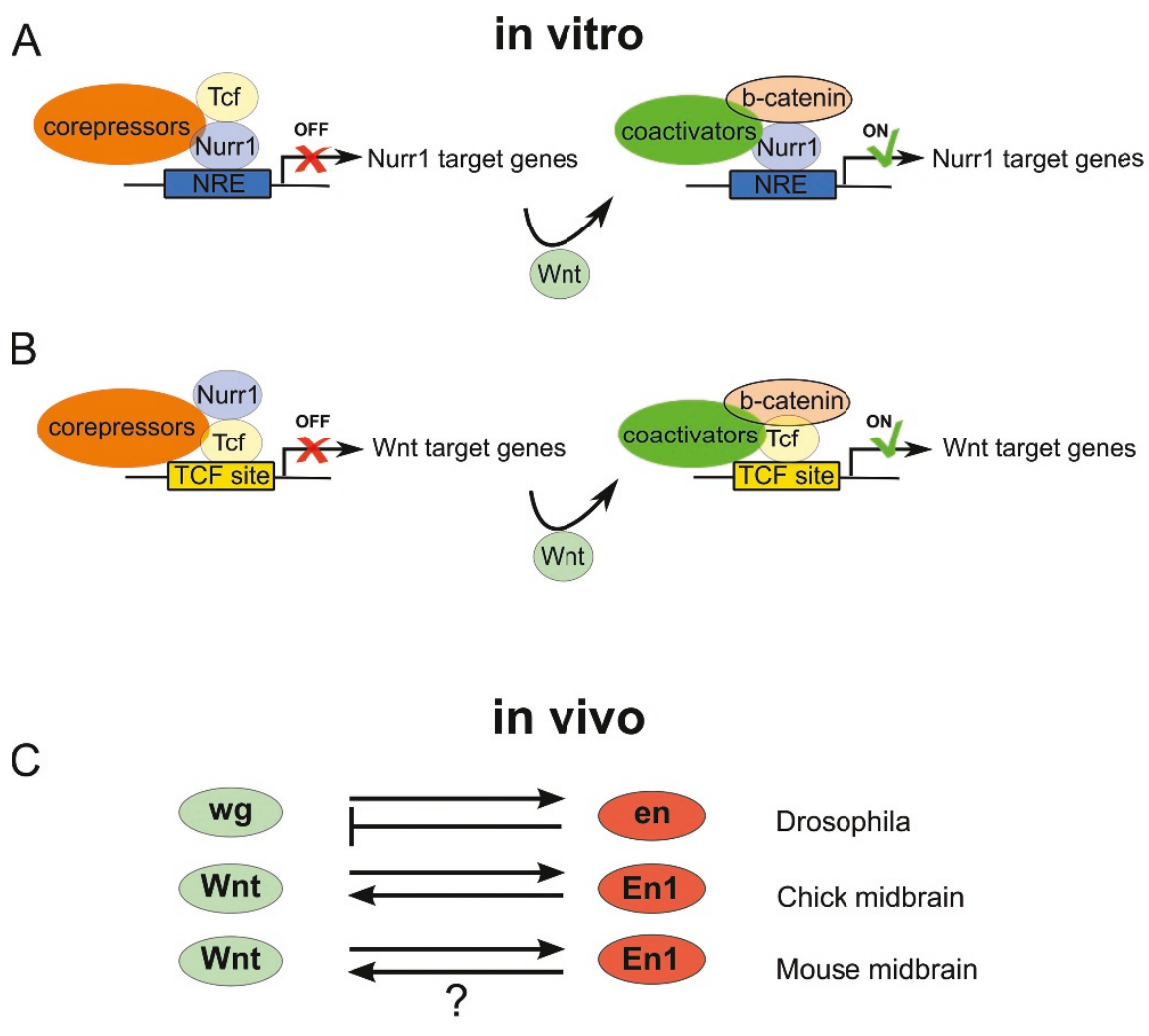

D

\section{in vitro}
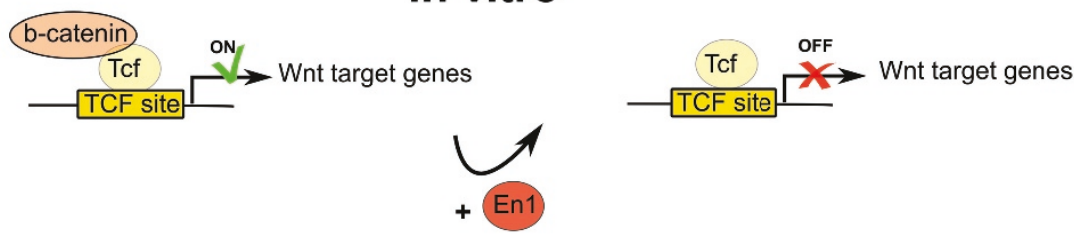

$E$

\section{Midbrain}
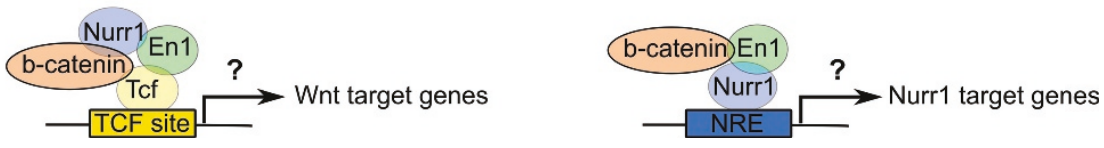

Figure 5 Interplay between Wnt, Nurr1 and En1 signaling in vitro and in vivo. (A) Model adapted from Kitagawa et al. [156]: Wnt signaling via $\beta$-catenin enhances the transcriptional activity of Nurr 1 in cells at Nurr1 responsive elements (NREs). In the absence of $\beta$-catenin, Nurr1 associates with T cell factor/lymphoid enhancer factor (TCF/LEF) in co-repressor complexes on NREs. After activation of Wnt signaling, $\beta$-catenin interacts with Nurr1 on NREs, competing with TCF/LEF for Nurr1 binding, resulting in the disruption of the co-repressors from the Nurr1 complex and the concomitant recruitment of coactivators. (B) Model adapted from Kitagawa et al. [156]: on the other hand, Nurr1 was observed to slightly modulate, in a negative way, the canonical Wnt signaling through association with the TCF/LEF region. After Wnt stimulation, $\beta$-catenin competed with Nurr1 for Lef binding on the TCF/LEF promoter site and disrupted Nurr1 binding, promoting Wnt-target gene transcription.

(C) Several studies in Drosophila and chick embryos have described interactions between En1/engrailed (en) and the Wnt/wg signaling pathway whereby engrailed expression is dependent on Wnt/wg signaling and vice versa. However, in Drosophila, engrailed expressing cells did not have active wg signaling. From mice studies it is known that Wnt signaling regulates En1 expression early in midbrain development. Whether the reverse happens in the mouse midbrain is not known. (D) In one cell culture study [216], it was observed that En1 can function as a negative regulator of $\beta$-catenin transcriptional activity in a post-translational manner (that is, by affecting $\beta$-catenin protein levels only). (E) Three questions remain currently unsolved: first, whether En1 cooperates with Nurr1 during mdDA development; second, whether Nurr1, En1 and canonical Wnt signaling cooperate in later stages of mdDA neuron development, such as in mIDA neuron specification; and third, whether Nurr1 and/or En1 regulate canonical Wnt signaling during mdDA neuron development. 
found to slightly modulate, in a negative way, the canonical Wnt signaling by being able to associate with the TCF/LEF region (Figure 5B). After Wnt stimulation, $\beta$-catenin would compete with Nurr1 for Lef1 binding on a TCF/LEF promoter site, such as the cyclin D1 promoter, and disrupt Nurr1 binding, promoting Wnt-target gene transcription [156]. A model to describe this mechanism was proposed and is shown in Figure 5A,B. Whether this model is valid for mdDA neuron differentiation and maintenance in vivo remains to be investigated. The question arises: do Nurr1 and $\beta$-catenin interact in vivo synergistically to drive Th expression? Previous studies strongly suggest that this is the case [204-206]. Importantly, besides the study from Kitagawa et al., synergistic interactions between $\beta$-catenin and several nuclear receptors have already been described [155]. Quite likely, $\beta$-catenin is involved in mdDA neurogeneis, cooperating with the Nurr1 transcription complex.

\section{Wnt signaling and En1}

In Drosophila and chick embryos, interactions between engrailed (en) and Wnt/wg signaling pathways have been described whereby engrailed expression is dependent on Wnt/wg signaling and vice versa [209-211] (Figure $5 \mathrm{C}$ ). However, in Drosophila, engrailed expressing cells did not have active wg signaling [209]. A modulation of Fz receptor expression by engrailed was shown in Drosophila wherein the expression of $\mathrm{Fz}$ is lower in engrailed-positive domains and, in the engrailed null mutant, the usual striped expression of $\mathrm{Fz}$ is disturbed, spreading everywhere in a non-segmental pattern [212]. Later, by means of chromatin immunoprecipitation (ChIP) assays, engrailed was established to be a direct repressor of Fz2 expression in vivo [213]. In mice, Wnt1 expression was found to overlap with $E n 1$ gene expression in the midbrain at 8.5 days post-coitus $[65,214,215]$, but while Wilkinson et al. [214] found Wnt1 expression in the midbrain after 12 days post-coitus, Davis and Joyner [65] did not observe overlapping expression domains between En1 and Wnt1 within the midbrain after this time point. As an explanation for this discrepancy they advance the fact that Wnt1 expression is punctuated, making it hard to get brain slices containing visible expression. So, a more detailed analysis of the Wnt/ $\beta$-catenin signaling in the mdDA system is needed. As mentioned above, inactivation of the Wnt1 gene leads to the deletion of the midbrain-hindbrain area with concomitant loss of En1 (its expression in the MHB region is initiated normally but is subsequently lost) [194,195,215]. Furthermore, the expression of En1 under the Wnt1 promoter rescues most of the Wnt1 phenotype, suggesting that En1 is a downstream target of Wnt1 [91] (Figure 5C). In conclusion, both Wnt1 and En1 cooperate in the patterning of the MHB region during early development.

In cell culture studies, it was observed that En1 can function as a negative regulator of $\beta$-catenin transcriptional activity in a Gro/TLE-independent manner (TLE: transducin-like enhancer of split 1) [216] (Figure 5D). Silencing En1 expression using small interfering RNA stimulated $\beta$-catenin transcriptional activity, measured by luciferase reporter assays. By Northern analysis and cycloheximide assays, Bachar-Dahan et al. [216] observed that En1 affects the level of a constitutively active form of $\beta$-catenin at a post-translational level only. They suggest that En 1 acts by destabilizing $\beta$-catenin via a proteasomal degradation pathway that is GSK3 $\beta$-independent [216].

As we mentioned above, there might be a link between En1 depletion and the onset of neurological disorders such as PD. A direct interaction between the PD-associated protein parkin and $\beta$-catenin has recently been observed [217]. In this study, increased levels of $\beta$-catenin activity were found in parkin mutant mice. This increase in Wnt- $\beta$-catenin signaling led to an increase in dopaminergic neuron proliferation and death [217], which is in contrast to the positive role Wnt- $\beta$-catenin signaling plays during mdDA neuron development. This might be due to the different needs in Wnt signaling activity in morbid adult dopaminergic midbrain tissue when compared to healthy one [158]. It is currently unknown whether En1 and canonical Wnt signaling cooperate in later stages of mdDA neuron development, such as in mdDA neuron specification and maintenance (Figure 5E).

\section{Conclusions and future perspectives}

The vertebrate mdDA system has been intensively studied in the past decades and an enormous wealth of information on the molecular cues controlling its development has been gathered. Our future challenge is to unravel in depth the gene cascades linking early induction to the differentiation and maintenance of mdDA neurons, eventually obtaining a complete picture of mdDA development (including the developmental origin and the molecular coding characterizing various mdDA subsets). Once this is accomplished, effective clinical treatments for mdDA-associated neurological disorders, such as PD, can be generated. As described in this review, current evidence strengthens the central roles that En1 and Wnt signaling might play in the advancement of these therapies, especially for PD. However, a detailed molecular characterization of the En1 mutant is lacking. Furthermore, the precise function of En 1 in some mdDA developmental processes is also not known, and questions such as whether En1 is essential 
in the differentiation of the mdDA system and is part of key transcriptional complexes mediating such processes (such as the Nurr1 complex) need to be investigated.

Concerning Wnt signaling, detailed knowledge about which developmental processes it regulates within a particular dopaminergic neuron, as well as which key players are involved, is still incipient. Furthermore, a more detailed characterization of $\mathrm{Wnt} / \beta$-catenin activity during ventral midbrain development is essential. Wnt signaling overlaps with that of En1 in time and space during CNS development and these two pathways interact functionally at least at one time point during embryonic mdDA development. It is now known that canonical Wnt signaling and En 1 cooperate in the genesis of a competent mdDA field during early development. However, whether Wnt signaling and En1 might cooperate in later midbrain developmental stages, such as in the differentiation of mdDA neurons, is still not known. Future research will have to focus on disclosing the En1 mutant phenotype and its relevance and eventual interplay with Wnt signaling during mdDA differentiation. Recent improvements in techniques, such as transcript expression profiling, ChIP-seq, proteomics, and mdDA neuronal cell isolation and culture, will certainly help unveil the molecular repertoire necessary to generate a mdDA neuron.

\section{Abbreviations \\ A/P: anterior-posterior; ChIP: chromatin immunoprecipitation; CNS: central nervous system; DA: dopamine; E: embryonic day; En: Engrailed; Fgf: fibroblast growth factor; FOXO: forkhead box O; Fz: Frizzled; GSK: glycogen synthase kinase; LEF: lymphoid enhancer factor; mdDA: mesodiencephalic dopaminergic; MHB: midbrain-hindbrain boundary; NRE: Nurr1 responsive element; PD: Parkinson's disease; Shh: sonic hedgehog; SNc: substantia nigra pars compacta; TCF: T cell factor; Th: tyrosine hydroxylase; VTA: ventral tegmental area.}

\section{Acknowledgements}

The work was supported by an NWO-ALW grant 816.02.012 to MPS.

\section{Authors' contributions}

MTMAS and MPS carried out the writing of the manuscript. Both authors have read and approved the final manuscript.

\section{Competing interests}

The authors declare that they have no competing interests.

Received: 24 January 2011 Accepted: 10 May 2011

Published: 10 May 2011

\section{References}

1. Loughlin SE, Fallon JH: Substantia nigra and ventral tegmental area projections to cortex: topography and collateralization. Neuroscience 1984, 11:425-435.

2. German DC, Manaye KF: Midbrain dopaminergic neurons (nuclei A8, A9, and $\mathrm{A} 10$ ): three-dimensional reconstruction in the rat. $J$ Comp Neurol 1993, 331:297-309

3. Bjorklund A, Dunnett SB: Dopamine neuron systems in the brain: an update. Trends Neurosci 2007, 30:194-202.

4. Hirsch E, Graybiel AM, Agid YA: Melanized dopaminergic neurons are differentially susceptible to degeneration in Parkinson's disease. Nature 1988, 334:345-348.
5. Barzilai A, Melamed E: Molecular mechanisms of selective dopaminergic neuronal death in Parkinson's disease. Trends Mol Med 2003, 9:126-132.

6. Kelley $\mathrm{AE}$, Berridge $\mathrm{KC}$ : The neuroscience of natural rewards: relevance to addictive drugs. J Neurosci 2002, 22:3306-3311.

7. Wightman RM, Robinson DL: Transient changes in mesolimbic dopamine and their association with 'reward'. J Neurochem 2002, 82:721-735.

8. Ungless MA: Dopamine: the salient issue. Trends Neurosci 2004, 27:702-706

9. Dailly E, Chenu F, Renard CE, Bourin M: Dopamine, depression and antidepressants. Fundam Clin Pharmacol 2004, 18:601-607.

10. Tzschentke TM, Schmidt WJ: Functional relationship among medial prefrontal cortex, nucleus accumbens, and ventral tegmental area in locomotion and reward. Crit Rev Neurobiol 2000, 14:131-142.

11. Sesack SR, Carr DB: Selective prefrontal cortex inputs to dopamine cells: implications for schizophrenia. Physiol Behav 2002, 77:513-517.

12. Liu A, Joyner AL: Early anterior/posterior patterning of the midbrain and cerebellum. Annu Rev Neurosci 2001, 24:869-896.

13. Wurst W, Bally-Cuif $L$ : Neural plate patterning: upstream and downstream of the isthmic organizer. Nat Rev Neurosci 2001, 2:99-108.

14. Smidt MP, Smits SM, Burbach JP: Molecular mechanisms underlying midbrain dopamine neuron development and function. Eur J Pharmacol 2003, 480:75-88.

15. Jessell TM: Neuronal specification in the spinal cord: inductive signals and transcriptional codes. Nat Rev Genet 2000, 1:20-29.

16. Puelles $L$, Rubenstein $J$ : Forebrain gene expression domains and the evolving prosomeric model. Trends Neurosci 2003, 26:469-476.

17. Smits SM, Burbach JP, Smidt MP: Developmental origin and fate of mesodiencephalic dopamine neurons. Prog Neurobio/ 2006, 78:1-16.

18. Lumsden A, Krumlauf R: Patterning the vertebrate neuraxis. Science 1996, 274:1109-1115

19. Rubenstein JL, Shimamura K, Martinez S, Puelles L: Regionalization of the prosencephalic neural plate. Annu Rev Neurosci 1998, 21:445-477.

20. Hynes M, Poulsen K, Tessier-Lavigne M, Rosenthal A: Control of neuronal diversity by the floor plate: contact-mediated induction of midbrain dopaminergic neurons. Cell 1995, 80:95-101.

21. Sato T, Araki I, Nakamura $\mathrm{H}$ : Inductive signal and tissue responsiveness defining the tectum and the cerebellum. Development 2001, 128:2461-2469.

22. Wang $M Z$, Jin $P$, Bumcrot DA, Marigo $V$, McMahon AP, Wang EA, Woolf $T$, Pang K: Induction of dopaminergic neuron phenotype in the midbrain by Sonic hedgehog protein. Nat Med 1995, 1:1184-1188.

23. Hynes M, Rosenthal A: Specification of dopaminergic and serotonergic neurons in the vertebrate CNS. Curr Opin Neurobiol 1999, 9:26-36.

24. Briscoe J, Ericson J: Specification of neuronal fates in the ventral neural tube. Curr Opin Neurobiol 2001, 11:43-49.

25. Ye W, Shimamura K, Rubenstein JL, Hynes MA, Rosenthal A: FGF and Shh signals control dopaminergic and serotonergic cell fate in the anterior neural plate. Cell 1998, 93:755-766.

26. Hynes M, Porter JA, Chiang C, Chang D, Tessier-Lavigne M, Beachy PA Rosenthal A: Induction of midbrain dopaminergic neurons by Sonic hedgehog. Neuron 1995, 15:35-44.

27. Patten I, Placzek M: The role of Sonic hedgehog in neural tube patterning. Cell Mol Life Sci 2000, 57:1695-1708.

28. Litingtung $Y$, Chiang C: Control of Shh activity and signaling in the neural tube. Dev Dyn 2000, 219:143-154.

29. Prakash N, Wurst W: Specification of midbrain territory. Cell Tissue Res 2004, 318:5-14

30. Alavian KN, Scholz C, Simon $\mathrm{HH}$ : Transcriptional regulation of mesencephalic dopaminergic neurons: the full circle of life and death. Mov Disord 2008, 23:319-328.

31. Castelo-Branco G, Arenas E: Function of Wnts in dopaminergic neuron development. Neurodegener Dis 2006, 3:5-11.

32. Simon HH, Saueressig H, Wurst W, Goulding MD, O'Leary DD: Fate of midbrain dopaminergic neurons controlled by the engrailed genes. J Neurosci 2001, 21:3126-3134.

33. Favor J, Sandulache R, Neuhäuser-Klaus A, Pretsch W, Chatterjee B, Senft E, Wurst W, Blanquet $V$, Grimes $P$, Spörle $R$, Schughart $K$ : The mouse Pax2(1 Neu) mutation is identical to a human PAX2 mutation in a family with renal-coloboma syndrome and results in developmental defects of the brain, ear, eye, and kidney. Proc Natl Acad Sci USA 1996, 93:13870-13875 
34. Urbanek P, Fetka I, Meisler MH, Busslinger M: Cooperation of Pax2 and Pax5 in midbrain and cerebellum development. Proc Natl Acad Sci USA 1997, 94:5703-5708.

35. Smidt MP, Asbreuk CH, Cox JJ, Chen H, Johnson RL, Burbach JP: A second independent pathway for development of mesencephalic dopaminergic neurons requires Lmx1b. Nat Neurosci 2000, 3:337-341.

36. Guo C, Qiu HY, Huang Y, Chen H, Yang RQ, Chen SD, Johnson RL, Chen ZF, Ding YQ: Lmx1b is essential for Fgf8 and Wnt1 expression in the isthmic organizer during tectum and cerebellum development in mice. Development 2007, 134:317-325.

37. Kittappa R, Chang WW, Awatramani RB, McKay RD: The foxa2 gene controls the birth and spontaneous degeneration of dopamine neurons in old age. PLOS Biol 2007, 5:e325.

38. Lee HS, Bae EJ, Yi SH, Shim JW, Jo AY, Kang JS, Yoon EH, Rhee YH, Park CH, Koh HC, Kim HJ, Choi HS, Han JW, Lee YS, Kim J, Li JY, Brundin P, Lee SH: Foxa2 and Nurr1 synergistically yield A9 nigral dopamine neurons exhibiting improved differentiation, function, and cell survival. Stem Cells 2010, 28:501-512.

39. Ang SL: Transcriptional control of midbrain dopaminergic neuron development. Development 2006, 133:3499-3506.

40. Andersson E, Tryggvason U, Deng Q, Friling S, Alekseenko Z, Robert B, Perlmann $T$, Ericson J: Identification of intrinsic determinants of midbrain dopamine neurons. Cell 2006, 124:393-405.

41. Prakash N, Wurst W: Genetic networks controlling the development of midbrain dopaminergic neurons. J Physiol 2006, 575:403-410.

42. Zetterström RH, Solomin L, Jansson L, Hoffer BJ, Olson L, Perlmann T: Dopamine neuron agenesis in Nurr1-deficient mice. Science 1997, 276:248-250.

43. Saucedo-Cardenas O, Quintana-Hau JD, Le WD, Smidt MP, Cox JJ, De Mayo F, Burbach JP, Conneely OM: Nurr1 is essential for the induction of the dopaminergic phenotype and the survival of ventral mesencephalic late dopaminergic precursor neurons. Proc Natl Acad Sci USA 1998, 95:4013-4018.

44. Jacobs FM, van Erp S, van der Linden AJ, von Oerthel L, Burbach JP Smidt MP: Pitx3 potentiates Nurr1 in dopamine neuron terminal differentiation through release of SMRT-mediated repression. Development 2009, 136:531-540.

45. Kawano H, Ohyama K, Kawamura K, Nagatsu I: Migration of dopaminergic neurons in the embryonic mesencephalon of mice. Brain Res Dev Brain Res 1995, 86:101-113.

46. Shults CW, Hashimoto R, Brady RM, Gage FH: Dopaminergic cells align along radial glia in the developing mesencephalon of the rat. Neuroscience 1990, 38:427-436.

47. Castro DS, Hermanson E, Joseph B, Wallén A, Aarnisalo P, Heller A Perlmann T: Induction of cell cycle arrest and morphological differentiation by Nurr1 and retinoids in dopamine MN9D cells. J Biol Chem 2001, 276:43277-43284.

48. Wallén A, Zetterström RH, Solomin L, Arvidsson M, Olson L, Perlmann T: Fate of mesencephalic AHD2-expressing dopamine progenitor cells in NURR1 mutant mice. Exp Cell Res 1999, 253:737-746.

49. Di Porzio U, Zuddas A, Cosenza-Murphy DB, Barker JL: Early appearance of tyrosine hydroxylase immunoreactive cells in the mesencephalon of mouse embryos. Int J Dev Neurosci 1990, 8:523-532.

50. Bayer SA, Wills KV, Triarhou LC, Ghetti B: Time of neuron origin and gradients of neurogenesis in midbrain dopaminergic neurons in the mouse. Exp Brain Res 1995, 105:191-199.

51. Alberi L, Sgado P, Simon HH: Engrailed genes are cell-autonomously required to prevent apoptosis in mesencephalic dopaminergic neurons. Development 2004, 131:3229-3236.

52. Marti J, Wills KV, Ghetti B, Bayer SA: A combined immunohistochemical and autoradiographic method to detect midbrain dopaminergic neurons and determine their time of origin. Brain Res Brain Res Protoc 2002, 9:197-205

53. Voorn P, Kalsbeek A, Jorritsma-Byham B, Groenewegen HJ: The pre- and postnatal development of the dopaminergic cell groups in the ventral mesencephalon and the dopaminergic innervation of the striatum of the rat. Neuroscience 1988, 25:857-887

54. Maxwell SL, Ho HY, Kuehner E, Zhao S, Li M: Pitx3 regulates tyrosine hydroxylase expression in the substantia nigra and identifies a subgroup of mesencephalic dopaminergic progenitor neurons during mouse development. Dev Biol 2005, 282:467-479.
55. Parent M, Parent A: Substantia nigra and Parkinson's disease: a brief history of their long and intimate relationship. Can J Neurol Sci 2010, 37:313-319.

56. Burbach JP, Smits S, Smidt MP: Transcription factors in the development of midbrain dopamine neurons. Ann N Y Acad Sci 2003, 991:61-68.

57. Wallen A, Perlmann T: Transcriptional control of dopamine neuron development. Ann N Y Acad Sci 2003, 991:48-60.

58. Smidt MP, Burbach JP: How to make a mesodiencephalic dopaminergic neuron. Nat Rev Neurosci 2007, 8:21-32.

59. Serrano N, Maschat F: Molecular mechanism of polyhomeotic activation by Engrailed. EMBO J 1998, 17:3704-3713.

60. Gibert JM: The evolution of engrailed genes after duplication and speciation events. Dev Genes Evol 2002, 212:307-318.

61. Manak JR, Scott MP: A class act: conservation of homeodomain protein functions. Dev Supp/ 1994, 61-77.

62. Davis CA, Noble-Topham SE, Rossant J, Joyner AL: Expression of the homeo box-containing gene En-2 delineates a specific region of the developing mouse brain. Genes Dev 1988, 2:361-371.

63. Davidson D, Graham E, Sime C, Hill R: A gene with sequence similarity to Drosophila engrailed is expressed during the development of the neural tube and vertebrae in the mouse. Development 1988, 104:305-316.

64. Zhong SC, Chen XS, Cai QY, Luo X, Chen XH, Liu J, Yao ZX: Dynamic expression and heterogeneous intracellular location of En-1 during late mouse embryonic development. Cells Tissues Organs 2010, 191:289-300.

65. Davis CA, Joyner AL: Expression patterns of the homeo box-containing genes En-1 and En-2 and the proto-oncogene int-1 diverge during mouse development. Genes Dev 1988, 2:1736-1744.

66. Davis CA, Holmyard DP, Millen KJ, Joyner AL: Examining pattern formation in mouse, chicken and frog embryos with an En-specific antiserum. Development 1991, 111:287-298

67. Wurst W, Auerbach AB, Joyner AL: Multiple developmental defects in Engrailed-1 mutant mice: an early mid-hindbrain deletion and patterning defects in forelimbs and sternum. Development 1994 120:2065-2075.

68. Matise MP, Joyner AL: Expression patterns of developmental control genes in normal and Engrailed-1 mutant mouse spinal cord reveal early diversity in developing interneurons. J Neurosci 1997, 17:7805-7816.

69. Millen KJ, Wurst W, Herrup K, Joyner AL: Abnormal embryonic cerebellar development and patterning of postnatal foliation in two mouse Engrailed-2 mutants. Development 1994, 120:695-706.

70. Hidalgo A: Growth and patterning from the engrailed interface. Int J Dev Biol 1998, 42:317-324

71. Joyner AL: Engrailed, Wnt and Pax genes regulate midbrain - hindbrain development. Trends Genet 1996, 12:15-20.

72. Weir MP, Edgar BA, Kornberg T, Schubiger G: Spatial regulation of engrailed expression in the Drosophila embryo. Genes Dev 1988, 2:1194-1203.

73. Condron BG, Patel NH, Zinn K: Engrailed controls glial/neuronal cell fate decisions at the midline of the central nervous system. Neuron 1994, 13:541-554.

74. Lundell MJ, Chu-LaGraff $Q$, Doe CQ, Hirsh J: The engrailed and huckebein genes are essential for development of serotonin neurons in the Drosophila CNS. Mol Cell Neurosci 1996, 7:46-61.

75. Friedman GC, O'Leary DD: Retroviral misexpression of engrailed genes in the chick optic tectum perturbs the topographic targeting of retinal axons. J Neurosci 1996, 16:5498-5509.

76. Itasaki N, Nakamura $\mathrm{H}$ : A role for gradient en expression in positional specification on the optic tectum. Neuron 1996, 16:55-62.

77. Saueressig H, Burrill J, Goulding M: Engrailed-1 and netrin-1 regulate axon pathfinding by association interneurons that project to motor neurons. Development 1999, 126:4201-4212.

78. Marie B, Bacon JP, Blagburn JM: Double-stranded RNA interference shows that Engrailed controls the synaptic specificity of identified sensory neurons. Curr Biol 2000, 10:289-292.

79. Marie B, Cruz-Orengo L, Blagburn JM: Persistent engrailed expression is required to determine sensory axon trajectory, branching, and target choice. J Neurosci 2002, 22:832-841.

80. Wizenmann A, Brunet I, Lam JS, Sonnier L, Beurdeley M, Zarbalis K, Weisenhorn-Vogt D, Weinl C, Dwivedy A, Joliot A, Wurst W, Holt C, Prochiantz A: Extracellular Engrailed participates in the topographic guidance of retinal axons in vivo. Neuron 2009, 64:355-366. 
81. Burrill JD, Moran L, Goulding MD, Saueressig H: PAX2 is expressed in multiple spinal cord interneurons, including a population of EN1+ interneurons that require PAX6 for their development. Development 1997 124:4493-4503.

82. Joliot A, Trembleau A, Raposo G, Calvet S, Volovitch M, Prochiantz A: Association of Engrailed homeoproteins with vesicles presenting caveolae-like properties. Development 1997, 124:1865-1875.

83. Prochiantz A, Joliot A: Can transcription factors function as cell-cell signaling molecules? Nat Rev Mol Cell Biol 2003, 4:814-819.

84. Brunet I, Weinl C, Piper M, Trembleau A, Volovitch M, Harris W, Prochiantz A, Holt C: The transcription factor Engrailed-2 guides retinal axons. Nature 2005, 438:94-98.

85. Cosgaya JM, Aranda A, Cruces J, Martin-Blanco E: Neuronal differentiation of PC12 cells induced by engrailed homeodomain is DNA-binding specific and independent of MAP kinases. J Cell Sci 1998, 111:2377-2384

86. Joliot A, Maizel A, Rosenberg D, Trembleau A, Dupas S, Volovitch M, Prochiantz A: Identification of a signal sequence necessary for the unconventional secretion of Engrailed homeoprotein. Curr Biol 1998, 8:856-863

87. Maizel A, Tassetto M, Filhol O, Cochet C, Prochiantz A, Joliot A: Engrailed homeoprotein secretion is a regulated process. Development 2002, 129:3545-3553.

88. Sonnier L, Le Pen G, Hartmann A, Bizot JC, Trovero F, Krebs MO, Prochiantz A: Progressive loss of dopaminergic neurons in the ventral midbrain of adult mice heterozygote for Engrailed1. J Neurosci 2007, 27:1063-1071.

89. Joyner AL, Herrup K, Auerbach BA, Davis CA, Rossant J: Subtle cerebellar phenotype in mice homozygous for a targeted deletion of the En-2 homeobox. Science 1991, 251:1239-1243.

90. Gerlai R, Millen KJ, Herrup K, Fabien K, Joyner AL, Roder J: Impaired motor learning performance in cerebellar En-2 mutant mice. Behav Neurosci 1996, 110:126-133.

91. Danielian PS, McMahon AP: Engrailed-1 as a target of the Wnt-1 signaling pathway in vertebrate midbrain development. Nature 1996, 383:332-334.

92. Hanks M, Wurst W, Anson-Cartwright L, Auerbach AB, Joyner AL: Rescue of the En-1 mutant phenotype by replacement of En-1 with En-2. Science 1995, 269:679-682.

93. Hanks MC, Loomis CA, Harris E, Tong CX, Anson-Cartwright L, Auerbach A, Joyner A: Drosophila engrailed can substitute for mouse Engrailed1 function in mid-hindbrain, but not limb development. Development 1998, 125:4521-4530.

94. Sgadò P, Albéri L, Gherbassi D, Galasso SL, Ramakers GM, Alavian KN, Smidt MP, Dyck RH, Simon HH: Slow progressive degeneration of nigral dopaminergic neurons in postnatal Engrailed mutant mice. Proc Natl Acad Sci USA 2006, 103:15242-15247.

95. Sgado P, Viaggi C, Fantacci C, Corsini GU: Characterization of the Engrailed mutant mice as experimental models for Parkinson's disease. Parkinsonism Relat Disord 2008, 14(Suppl 2):S103-106.

96. Le Pen G, Sonnier L, Hartmann A, Bizot JC, Trovero F, Krebs MO, Prochiantz A: Progressive loss of dopaminergic neurons in the ventral midbrain of adult mice heterozygote for Engrailed1: a new genetic model for Parkinson's disease? Parkinsonism Relat Disord 2008, 14(Suppl 2):S107-111.

97. Andersen JK: Does neuronal loss in Parkinson's disease involve programmed cell death? Bioessays 2001, 23:640-646.

98. Hartmann A, Hunot S, Michel PP, Muriel MP, Vyas S, Faucheux BA, MouattPrigent A, Turmel H, Srinivasan A, Ruberg M, Evan Gl, Agid Y, Hirsch EC: Caspase-3: A vulnerability factor and final effector in apoptotic death of dopaminergic neurons in Parkinson's disease. Proc Natl Acad Sci USA 2000, 97:2875-2880.

99. Olanow CW, Tatton WG: Etiology and pathogenesis of Parkinson's disease. Annu Rev Neurosci 1999, 22:123-144.

100. Polymeropoulos MH, Lavedan C, Leroy E, Ide SE, Dehejia A, Dutra A, Pike B, Root H, Rubenstein J, Boyer R, Stenroos ES, Chandrasekharappa S, Athanassiadou A, Papapetropoulos T, Johnson WG, Lazzarini AM, Duvoisin RC, Di lorio G, Golbe LI, Nussbaum RL: Mutation in the alphasynuclein gene identified in families with Parkinson's disease. Science 1997, 276:2045-2047.

101. Simon HH, Thuret S, Alberi L: Midbrain dopaminergic neurons: control of their cell fate by the engrailed transcription factors. Cell Tissue Res 2004, 318:53-61.
102. Haubenberger D, Reinthaler E, Mueller JC, Pirker W, Katzenschlager R, Froehlich R, Bruecke T, Daniel G, Auff E, Zimprich A: Association of transcription factor polymorphisms PITX3 and EN1 with Parkinson's disease. Neurobiol Aging 2011, 32:302-307.

103. Klingensmith J, Nusse R: Signaling by wingless in Drosophila. Dev Biol 1994, 166:396-414.

104. Nusse R, Brown A, Papkoff J, Scambler P, Shackleford G, McMahon A, Moon R, Varmus H: A new nomenclature for int-1 and related genes: the Wnt gene family. Cell 1991, 64:231.

105. Rijsewijk F, Schuermann M, Wagenaar E, Parren P, Weigel D, Nusse R: The Drosophila homolog of the mouse mammary oncogene int- 1 is identical to the segment polarity gene wingless. Cell 1987, 50:649-657.

106. Nusse R, Varmus HE: Wnt genes. Cell 1992, 69:1073-1087.

107. Willert K, Brown JD, Danenberg E, Duncan AW, Weissman IL, Reya T, Yates JR, Nusse R: Wnt proteins are lipid-modified and can act as stem cell growth factors. Nature 2003, 423:448-452.

108. The Wnt Homepage. [http://www.stanford.edu/group/nusselab/cgi-bin/ wnt/].

109. Guder C, Philipp I, Lengfeld T, Watanabe H, Hobmayer B, Holstein TW: The Wnt code: cnidarians signal the way. Oncogene 2006, 25:7450-7460.

110. Croce JC, McClay DR: Evolution of the Wht pathways. Methods Mol Biol 2008, 469:3-18.

111. Nusse R, Fuerer C, Ching W, Harnish K, Logan C, Zeng A, ten Berge D, Kalani Y: Wnt signaling and stem cell control. Cold Spring Harb Symp Quant Biol 2008, 73:59-66.

112. Moon RT, Kohn AD, De Ferrari GV, Kaykas A: WNT and beta-catenin signaling: diseases and therapies. Nat Rev Genet 2004, 5:691-701.

113. Sancho E, Batlle E, Clevers H: Signaling pathways in intestinal development and cancer. Annu Rev Cell Dev Biol 2004, 20:695-723.

114. Taipale J, Beachy PA: The Hedgehog and Wnt signaling pathways in cancer. Nature 2001, 411:349-354.

115. Logan CY, Nusse R: The Wnt signaling pathway in development and disease. Annu Rev Cell Dev Biol 2004, 20:781-810.

116. Zecca M, Basler K, Struhl G: Direct and long-range action of a wingless morphogen gradient. Cell 1996, 87:833-844.

117. Megason SG, McMahon AP: A mitogen gradient of dorsal midline Wnts organizes growth in the CNS. Development 2002, 129:2087-2098.

118. Strigini M, Cohen SM: Wingless gradient formation in the Drosophila wing. Curr Biol 2000, 10:293-300.

119. Neumann CJ, Cohen SM: Long-range action of Wingless organizes the dorsal-ventral axis of the Drosophila wing. Development 1997, 124:871-880.

120. Nusse R: Wnt signaling in disease and in development. Cell Res 2005, $15: 28-32$

121. Carlson ME, Silva HS, Conboy IM: Aging of signal transduction pathways, and pathology. Exp Cell Res 2008, 314:1951-1961.

122. Clevers $\mathrm{H}$ : Wnt/beta-catenin signaling in development and disease. Cell 2006, 127:469-480

123. MacDonald BT, Tamai $K$, He X: Wnt/beta-catenin signaling: components, mechanisms, and diseases. Dev Cell 2009, 17:9-26.

124. Polakis P: Wnt signaling and cancer. Genes Dev 2000, 14:1837-1851.

125. Kikuchi A, Yamamoto H, Sato A: Selective activation mechanisms of Wnt signaling pathways. Trends Cell Biol 2009, 19:119-129.

126. Angers S, Moon RT: Proximal events in Wnt signal transduction. Nat Rev Mol Cell Biol 2009, 10:468-477.

127. Green JL, Kuntz SG, Sternberg PW: Ror receptor tyrosine kinases: orphans no more. Trends Cell Biol 2008, 18:536-544.

128. Vlad A, Rohrs S, Klein-Hitpass L, Muller O: The first five years of the Wnt targetome. Cell Signal 2008, 20:795-802.

129. Cadigan KM, Liu YI: Wnt signaling: complexity at the surface. J Cell Sci 2006, 119:395-402.

130. Gordon MD, Nusse R: Wnt signaling: multiple pathways, multiple receptors, and multiple transcription factors. J Biol Chem 2006, 281:22429-22433.

131. Jamora C, Fuchs E: Intercellular adhesion, signaling and the cytoskeleton. Nat Cell Biol 2002, 4:E101-108.

132. Klaus A, Birchmeier W: Wnt signaling and its impact on development and cancer. Nat Rev Cancer 2008, 8:387-398.

133. Reya T, Clevers H: Wnt signaling in stem cells and cancer. Nature 2005, 434:843-850. 
134. Teo R, Mohrlen F, Plickert G, Muller WA, Frank U: An evolutionary conserved role of Wnt signaling in stem cell fate decision. Dev Biol 2006, 289:91-99.

135. Tzahor E: Wnt/beta-catenin signaling and cardiogenesis: timing does matter. Dev Cell 2007, 13:10-13

136. Boonen RA, van Tijn P, Zivkovic D: Wnt signaling in Alzheimer's disease: up or down, that is the question. Ageing Res Rev 2009, 8:71-82.

137. Behrens Ml, Lendon C, Roe CM: A common biological mechanism in cancer and Alzheimer's disease? Curr Alzheimer Res 2009, 6:196-204.

138. Zhang Z, Hartmann H, Do VM, Abramowski D, Sturchler-Pierrat C, Staufenbiel M, Sommer B, van de Wetering M, Clevers H, Saftig P, De Strooper B, He X, Yankner BA: Destabilization of beta-catenin by mutations in presenilin-1 potentiates neuronal apoptosis. Nature 1998, 395:698-702.

139. Chacon MA, Varela-Nallar $L$, Inestrosa NC: Frizzled-1 is involved in the neuroprotective effect of Wnt3a against Abeta oligomers. J Cell Physiol 2008, 217:215-227

140. Cadigan KM: Wnt-beta-catenin signaling. Curr Biol 2008, 18:R943-947.

141. Liu C, Li Y, Semenov M, Han C, Baeg GH, Tan Y, Zhang Z, Lin X, He X: Control of beta-catenin phosphorylation/degradation by a dual-kinase mechanism. Cell 2002, 108:837-847

142. He $X$, Semenov M, Tamai K, Zeng X: LDL receptor-related proteins 5 and 6 in Wnt/beta-catenin signaling: arrows point the way. Development 2004, 131:1663-1677

143. Zeng X, Tamai K, Doble B, Li S, Huang H, Habas R, Okamura H, Woodgett J, He X: A dual-kinase mechanism for Wnt co-receptor phosphorylation and activation. Nature 2005, 438:873-877.

144. Davidson G, Wu W, Shen J, Bilic J, Fenger U, Stannek P, Glinka A, Niehrs C: Casein kinase 1 gamma couples Wnt receptor activation to cytoplasmic signal transduction. Nature 2005, 438:867-872.

145. Bilic J, Huang YL, Davidson G, Zimmermann T, Cruciat CM, Bienz M, Niehrs C: Wnt induces LRP6 signalosomes and promotes dishevelleddependent LRP6 phosphorylation. Science 2007, 316:1619-1622.

146. Huang $H, H e X$ : Wnt/beta-catenin signaling: new (and old) players and new insights. Curr Opin Cell Biol 2008, 20:119-125.

147. Mosimann C, Hausmann G, Basler K: Beta-catenin hits chromatin: regulation of Wnt target gene activation. Nat Rev Mol Cell Biol 2009, 10:276-286.

148. Willert K, Jones KA: Wnt signaling: is the party in the nucleus? Genes Dev 2006, 20:1394-1404.

149. Jin T, George Fantus I, Sun J: Wnt and beyond Wnt: multiple mechanisms control the transcriptional property of beta-catenin. Cell Signal 2008, 20:1697-1704.

150. Yi F, Sun J, Lim GE, Fantus IG, Brubaker PL, Jin T: Cross talk between the insulin and Wnt signaling pathways: evidence from intestinal endocrine L cells. Endocrinology 2008, 149:2341-2351.

151. Essers MA, de Vries-Smits LM, Barker N, Polderman PE, Burgering BM, Korswagen $\mathrm{HC}$ : Functional interaction between beta-catenin and FOXO in oxidative stress signaling. Science 2005, 308:1181-1184.

152. Manolagas SC, Almeida M: Gone with the Wnts: beta-catenin, T-cell factor, forkhead box $\mathrm{O}$, and oxidative stress in age-dependent diseases of bone, lipid, and glucose metabolism. Mol Endocrinol 2007, 21:2605-2614.

153. Hoogeboom D, Essers MA, Polderman PE, Voets E, Smits LM, Burgering BM: Interaction of FOXO with beta-catenin inhibits beta-catenin/T cell factor activity. J Biol Chem 2008, 283:9224-9230.

154. Greer EL, Brunet A: FOXO transcription factors at the interface between longevity and tumor suppression. Oncogene 2005, 24:7410-7425.

155. Mulholland DJ, Dedhar S, Coetzee GA, Nelson CC: Interaction of nuclear receptors with the $\mathrm{Wnt} /$ beta-catenin/Tcf signaling axis: Wnt you like to know? Endocr Rev 2005, 26:898-915.

156. Kitagawa H, Ray WJ, Glantschnig H, Nantermet PV, Yu Y, Leu CT, Harada S, Kato $S$, Freedman LP: A regulatory circuit mediating convergence between Nurr 1 transcriptional regulation and Wnt signaling. Mol Cell Biol 2007, 27:7486-7496.

157. Grigoryan T, Wend P, Klaus A, Birchmeier W: Deciphering the function of canonical Wnt signals in development and disease: conditional loss- and gain-of-function mutations of beta-catenin in mice. Genes Dev 2008, 22:2308-2341.

158. Inestrosa NC, Arenas E: Emerging roles of Wnts in the adult nervous system. Nat Rev Neurosci 2010, 11:77-86.
159. Fischer T, Guimera J, Wurst W, Prakash N: Distinct but redundant expression of the Frizzled Wnt receptor genes at signaling centers of the developing mouse brain. Neuroscience 2007, 147:693-711.

160. Pinson Kl, Brennan J, Monkley S, Avery BJ, Skarnes WC: An LDL-receptorrelated protein mediates Wnt signaling in mice. Nature 2000 407:535-538

161. Oishi I, Suzuki H, Onishi N, Takada R, Kani S, Ohkawara B, Koshida I, Suzuki K, Yamada G, Schwabe GC, Mundlos S, Shibuya H, Takada S, Minami $Y$ : The receptor tyrosine kinase Ror2 is involved in non-canonical Wnt5a/JNK signaling pathway. Genes Cells 2003, 8:645-654.

162. Parr BA, Shea MJ, Vassileva G, McMahon AP: Mouse Wnt genes exhibit discrete domains of expression in the early embryonic CNS and limb buds. Development 1993, 119:247-261

163. Yoshikawa Y, Fujimori T, McMahon AP, Takada S: Evidence that absence of Wnt-3a signaling promotes neuralization instead of paraxial mesoderm development in the mouse. Dev Biol 1997, 183:234-242.

164. Pöpperl H, Schmidt C, Wilson V, Hume CR, Dodd J, Krumlauf R, Beddington RS: Misexpression of Cwnt8C in the mouse induces an ectopic embryonic axis and causes a truncation of the anterior neuroectoderm. Development 1997, 124:2997-3005.

165. Mukhopadhyay M, Shtrom S, Rodriguez-Esteban C, Chen L, Tsukui T, Gomer L, Dorward DW, Glinka A, Grinberg A, Huang SP, Niehrs C, Izpisúa Belmonte JC, Westphal H: Dickkopf1 is required for embryonic head induction and limb morphogenesis in the mouse. Dev Cell 2001, 1:423-434.

166. Davidson G, Mao B, del Barco Barrantes I, Niehrs C: Kremen proteins interact with Dickkopf1 to regulate anteroposterior CNS patterning. Development 2002, 129:5587-5596.

167. Schuller $\mathrm{U}$, Rowitch $\mathrm{DH}$ : Beta-catenin function is required for cerebellar morphogenesis. Brain Res 2007, 1140:161-169.

168. Chenn A, Walsh CA: Regulation of cerebral cortical size by control of cell cycle exit in neural precursors. Science 2002, 297:365-369.

169. Zechner D, Fujita Y, Hülsken J, Müller T, Walther I, Taketo MM, Crenshaw EB, Birchmeier W, Birchmeier C: beta-Catenin signals regulate cell growth and the balance between progenitor cell expansion and differentiation in the nervous system. Dev Biol 2003, 258:406-418.

170. Brault V, Moore R, Kutsch S, Ishibashi M, Rowitch DH, McMahon AP, Sommer L, Boussadia O, Kemler R: Inactivation of the beta-catenin gene by Wnt1-Cre-mediated deletion results in dramatic brain malformation and failure of craniofacial development. Development 2001, 128:1253-1264.

171. Panhuysen M, Vogt Weisenhorn DM, Blanquet V, Brodski C, Heinzmann U, Beisker W, Wurst W: Effects of Wnt1 signaling on proliferation in the developing mid-/hindbrain region. Mol Cell Neurosci 2004, 26:101-111.

172. Lee SM, Tole S, Grove E, McMahon AP: A local Wnt-3a signal is required for development of the mammalian hippocampus. Development 2000, 127:457-467.

173. Galceran J, Miyashita-Lin EM, Devaney E, Rubenstein JL, Grosschedl R: Hippocampus development and generation of dentate gyrus granule cells is regulated by LEF1. Development 2000, 127:469-482.

174. Viti J, Gulacsi A, Lillien L: Wnt regulation of progenitor maturation in the cortex depends on Shh or fibroblast growth factor 2. J Neurosci 2003, 23:5919-5927.

175. Muroyama Y, Fujihara M, Ikeya M, Kondoh H, Takada S: Wnt signaling plays an essential role in neuronal specification of the dorsal spinal cord. Genes Dev 2002, 16:548-553.

176. Muroyama $Y$, Kondoh $H$, Takada S: Wnt proteins promote neuronal differentiation in neural stem cell culture. Biochem Biophys Res Commun 2004, 313:915-921.

177. Lee HY, Kléber M, Hari L, Brault V, Suter U, Taketo MM, Kemler R, Sommer L: Instructive role of Wnt/beta-catenin in sensory fate specification in neural crest stem cells. Science 2004, 303:1020-1023.

178. Hirabayashi Y, Itoh Y, Tabata H, Nakajima K, Akiyama T, Masuyama N, Gotoh Y: The Wnt/beta-catenin pathway directs neuronal differentiation of cortical neural precursor cells. Development 2004, 131:2791-2801.

179. Chenn A, Walsh CA: Increased neuronal production, enlarged forebrains and cytoarchitectural distortions in beta-catenin overexpressing transgenic mice. Cereb Cortex 2003, 13:599-606.

180. Yoshikawa S, McKinnon RD, Kokel M, Thomas JB: Wnt-mediated axon guidance via the Drosophila Derailed receptor. Nature 2003, 422:583-588. 
181. Lu W, Yamamoto V, Ortega B, Baltimore D: Mammalian Ryk is a Wnt coreceptor required for stimulation of neurite outgrowth. Cell 2004, 119:97-108.

182. Lyuksyutova Al, Lu CC, Milanesio N, King LA, Guo N, Wang Y, Nathans J, Tessier-Lavigne M, Zou Y: Anterior-posterior guidance of commissural axons by Wnt-frizzled signaling. Science 2003, 302:1984-1988.

183. Bovolenta P, Rodriguez J, Esteve P: Frizzled/RYK mediated signaling in axon guidance. Development 2006, 133:4399-4408.

184. Hall AC, Lucas FR, Salinas PC: Axonal remodeling and synaptic differentiation in the cerebellum is regulated by WNT-7a signaling. Cell 2000, 100:525-535

185. Krylova O, Herreros J, Cleverley KE, Ehler E, Henriquez JP, Hughes SM, Salinas PC: WNT-3, expressed by motoneurons, regulates terminal arborization of neurotrophin-3-responsive spinal sensory neurons. Neuron 2002, 35:1043-1056.

186. Korkut C, Budnik V: WNTs tune up the neuromuscular junction. Nat ReV Neurosci 2009, 10:627-634.

187. Salinas PC, Zou Y: Wnt signaling in neural circuit assembly. Annu Rev Neurosci 2008, 31:339-358.

188. Arikkath J, Reichardt LF: Cadherins and catenins at synapses: roles in synaptogenesis and synaptic plasticity. Trends Neurosci 2008, 31:487-494.

189. Yu X, Malenka RC: Beta-catenin is critical for dendritic morphogenesis. Nat Neurosci 2003, 6:1169-1177.

190. Rosso SB, Sussman D, Wynshaw-Boris A, Salinas PC: Wnt signaling through Dishevelled, Rac and JNK regulates dendritic development. Nat Neurosci 2005, 8:34-42.

191. Li G, Pleasure SJ: Morphogenesis of the dentate gyrus: what we are learning from mouse mutants. Dev Neurosci 2005, 27:93-99.

192. Gulacsi AA, Anderson SA: Beta-catenin-mediated Wnt signaling regulates neurogenesis in the ventral telencephalon. Nat Neurosci 2008, 11:1383-1391.

193. Amoyel $M$, Cheng YC, Jiang YJ, Wilkinson DG: Wnt1 regulates neurogenesis and mediates lateral inhibition of boundary cell specification in the zebrafish hindbrain. Development 2005, 132:775-785.

194. Thomas KR, Capecchi MR: Targeted disruption of the murine int-1 protooncogene resulting in severe abnormalities in midbrain and cerebellar development. Nature 1990, 346:847-850.

195. McMahon AP, Bradley A: The Wnt-1 (int-1) proto-oncogene is required for development of a large region of the mouse brain. Cell 1990, 62:1073-1085.

196. Chilov D, Sinjushina N, Saarimaki-Vire J, Taketo MM, Partanen J: betaCatenin regulates intercellular signaling networks and cell-type specific transcription in the developing mouse midbrain-rhombomere 1 region. PLoS One 2010, 5:e10881.

197. Castelo-Branco G, Andersson ER, Minina E, Sousa KM, Ribeiro D, Kokubu C, Imai K, Prakash N, Wurst W, Arenas E: Delayed dopaminergic neuron differentiation in Lrp6 mutant mice. Dev Dyn 2010, 239:211-221.

198. Stuebner S, Faus-Kessler T, Fischer T, Wurst W, Prakash N: Fzd3 and Fzd6 deficiency results in a severe midbrain morphogenesis defect. Dev Dyn 2010, 239:246-260

199. Chung S, Leung A, Han BS, Chang MY, Moon Jl, Kim CH, Hong S, Pruszak J, Isacson O, Kim KS: Wnt1-Imx1a forms a novel autoregulatory loop and controls midbrain dopaminergic differentiation synergistically with the SHH-FoxA2 pathway. Cell Stem Cell 2009, 5:646-658.

200. Ciani L, Salinas PC: WNTs in the vertebrate nervous system: from patterning to neuronal connectivity. Nat Rev Neurosci 2005, 6:351-362.

201. Castelo-Branco G, Wagner J, Rodriguez FJ, Kele J, Sousa K, Rawal N, Pasolli HA, Fuchs E, Kitajewski J, Arenas E: Differential regulation of midbrain dopaminergic neuron development by Wnt-1, Wnt-3a, and Wnt-5a. Proc Natl Acad Sci USA 2003, 100:12747-12752

202. Rawal N, Castelo-Branco G, Sousa KM, Kele J, Kobayashi K, Okano H, Arenas E: Dynamic temporal and cell type-specific expression of Wnt signaling components in the developing midbrain. Exp Cell Res 2006, 312:1626-1636

203. Joksimovic M, Yun BA, Kittappa R, Anderegg AM, Chang WW, Taketo MM, McKay RD, Awatramani RB: Wnt antagonism of Shh facilitates midbrain floor plate neurogenesis. Nat Neurosci 2009, 12:125-131.

204. Castelo-Branco G, Rawal N, Arenas E: GSK-3beta inhibition/beta-catenin stabilization in ventral midbrain precursors increases differentiation into dopamine neurons. J Cell Sci 2004, 117:5731-5737.
205. Tang M, Miyamoto Y, Huang EJ: Multiple roles of beta-catenin in controlling the neurogenic niche for midbrain dopamine neurons. Development 2009, 136:2027-2038

206. Tang M, Villaescusa JC, Luo SX, Guitarte C, Lei S, Miyamoto Y, Taketo MM, Arenas E, Huang EJ: Interactions of Wnt/beta-catenin signaling and sonic hedgehog regulate the neurogenesis of ventral midbrain dopamine neurons. J Neurosci 2010, 30:9280-9291.

207. Prakash N, Brodski C, Naserke T, Puelles E, Gogoi R, Hall A, Panhuysen M, Echevarria D, Sussel L, Weisenhorn DM, Martinez S, Arenas E, Simeone A Wurst W: A Wnt1-regulated genetic network controls the identity and fate of midbrain-dopaminergic progenitors in vivo. Development 2006, 133:89-98.

208. Sousa KM, Villaescusa JC, Cajanek L, Ondr JK, Castelo-Branco G, Hofstra W, Bryja V, Palmberg C, Bergman T, Wainwright B, Lang RA, Arenas E: Wnt2 regulates progenitor proliferation in the developing ventral midbrain. J Biol Chem 2010, 285:7246-7253.

209. Heemskerk J, DiNardo S, Kostriken R, O'Farrell PH: Multiple modes of engrailed regulation in the progression towards cell fate determination. Nature 1991, 352:404-410.

210. DiNardo S, Sher E, Heemskerk-Jongens J, Kassis JA, O'Farrell PH: Two-tiered regulation of spatially patterned engrailed gene expression during Drosophila embryogenesis. Nature 1988, 332:604-609.

211. Araki I, Nakamura H: Engrailed defines the position of dorsal dimesencephalic boundary by repressing diencephalic fate. Development 1999, 126:5127-5135.

212. Lecourtois M, Alexandre C, Dubois L, Vincent JP: Wingless capture by Frizzled and Frizzled2 in Drosophila embryos. Dev Biol 2001, 235:467-475.

213. Solano PJ, Mugat B, Martin D, Girard F, Huibant JM, Ferraz C, Jacq B, Demaille J, Maschat F: Genome-wide identification of in vivo Drosophila Engrailed-binding DNA fragments and related target genes. Development 2003, 130:1243-1254

214. Wilkinson DG, Bailes JA, McMahon AP: Expression of the proto-oncogene int- 1 is restricted to specific neural cells in the developing mouse embryo. Cell 1987, 50:79-88.

215. McMahon AP, Joyner AL, Bradley A, McMahon JA: The midbrain-hindbrain phenotype of Wnt-1-/Wnt-1- mice results from stepwise deletion of engrailed-expressing cells by 9.5 days postcoitum. Cell 1992, 69:581-595.

216. Bachar-Dahan L, Goltzmann J, Yaniv A, Gazit A: Engrailed-1 negatively regulates beta-catenin transcriptional activity by destabilizing betacatenin via a glycogen synthase kinase-3beta-independent pathway. Mol Biol Cell 2006, 17:2572-2580.

217. Rawal N, Corti O, Sacchetti P, Ardilla-Osorio H, Sehat B, Brice A, Arenas E: Parkin protects dopaminergic neurons from excessive $\mathrm{Wnt} /$ beta-catenin signaling. Biochem Biophys Res Commun 2009, 388:473-478.

doi:10.1186/1749-8104-6-23

Cite this article as: Alves dos Santos and Smidt: En1 and Wnt signaling in midbrain dopaminergic neuronal development. Neural Development $20116: 23$.

\section{Submit your next manuscript to BioMed Central and take full advantage of:}

- Convenient online submission

- Thorough peer review

- No space constraints or color figure charges

- Immediate publication on acceptance

- Inclusion in PubMed, CAS, Scopus and Google Scholar

- Research which is freely available for redistribution

Submit your manuscript at www.biomedcentral com/submit
C Biomed Central 